\title{
Arne Torkildsen and the ventriculocisternal shunt: the first clinically successful shunt for hydrocephalus
}

\author{
Per Kristian Eide, MD, PhD, and Tryggve Lundar, MD, PhD \\ Department of Neurosurgery, Oslo University Hospital-Rikshospitalet; and Faculty of Medicine, University of Oslo, Norway \\ Arne Torkildsen was a pioneering Norwegian neurosurgeon who introduced the ventriculocisternal shunt, the first clini- \\ cally successful shunt for CSF diversion in hydrocephalus. The procedure, usually referred to as ventriculocisternostomy \\ (VCS), Torkildsen's operation, or Torkildsen's shunt, became internationally recognized as an efficient operation for the \\ treatment of noncommunicating hydrocephalus. The operation gained widespread use in the 1940s and 1950s before \\ the introduction of extracranial shunts. In this paper, the authors look more closely at Torkildsen's development of the \\ VCS and examine how this surgical approach differed from other procedures for treating hydrocephalus before World \\ War II. Long-term results of the VCS are presented. \\ http://thejns.org/doi/abs/10.3171/2015.1.JNS142659
}

KEY WORDS hydrocephalus; ventriculocisternostomy; shunt; Arne Torkildsen; history

$\Lambda$ RNE Torkildsen was a pioneering Norwegian neurosurgeon best known for developing ventriculocisternostomy (VCS), the first clinically successful procedure for shunting of CSF. The procedure soon became internationally accepted as a standard procedure for treating obstruction of the aqueduct/posterior third ventricle and is usually referred to as the Torkildsen operation, Torkildsen tube, or Torkildsen shunt. ${ }^{32}$

Torkildsen became the first neurosurgeon at the National Hospital (Rikshospitalet) in Oslo, Norway. VCS for the treatment of noncommunicating hydrocephalus was his most important contribution to neurosurgery. In this paper, we pay tribute to his innovative operative approach and also review the treatment of hydrocephalus at the time when Torkildsen introduced the procedure.

\section{Arne Torkildsen and Wilder Penfield}

Arne Torkildsen (September 14, 1899-March 7, 1968; Fig. 1) earned his MD degree at the University of Oslo, Norway, in 1927. He spent a year (1929-1930) at the National Hospital, Queen Square, London, studying neurology, and then stayed at the Royal Victoria Hospital in
Montreal for 4 years (1930-1934) together with Wilder Penfield (1891-1976). ${ }^{20}$ Torkildsen became one of his first four fellows. ${ }^{19}$ During this period he conducted studies on the anatomy of the cerebral ventricular system ${ }^{57}$ and on intracranial gliomas ${ }^{61}$ and head injuries. ${ }^{60}$

\section{Torkildsen at the National Hospital (Rikshospitalet) in Oslo}

Torkildsen stayed with Penfield for 4 years and returned to Norway in 1935 to practice neurosurgery. At that time, however, no neurosurgical service had been established in his home country. Vilhelm Magnus ${ }^{23}$ was the first neurosurgeon in Norway; he practiced in a private hospital from 1903 until his death in 1929. However, he had no students, which created a vacuum after his death. During the 1930s some neurosurgical operations were done in the Rikshospitalet Department of Surgery, headed by Professor Ragnvald Ingebrigtsen (1882-1975). Professor Ingebrigtsen had spent some months with Harvey Cushing in Boston and had gained experience in the treatment of spinal cord and brain tumors.

In 1935, at the age of 35, Torkildsen started out as a vol- 
unteer within the Rikshospitalet Department of Neurology, headed by Professor Georg Herman Monrad-Krohn (1884-1964). A small operating room had been established within the Department of Neurology. It was not very well equipped and the staff was not well trained.

Torkildsen described this initial period, from February 1935 to March 1938, in a monograph published in Norwegian in $1939 .{ }^{58}$ From 19 operations in 1935, the number grew to 164 in 1938. During this period, Torkildsen performed 87 craniotomies (59 supratentorial and 28 infratentorial). The overall surgical mortality rate was $25 \%$ (15/59 patients) for supratentorial and 21\% (6/28 patients) for infratentorial procedures. The learning curve was steep, as the mortality rate improved to $10 \%$ (3/31 patients) in his later series. Surgery was mostly done using local anesthesia, with the additional use of ether in children. Torkildsen performed the surgeries in a single session and avoided staged surgeries.

Torkildsen achieved results in these early series that were rather good in comparison with the experiences of prominent contemporary surgeons. For example, in 1931 Harvey Cushing reported a mortality rate of $19.7 \%$ (15/76 patients in a series of 113 procedures) in his cerebellar astrocytoma series. ${ }^{7}$ In another series of 149 astrocytomas, Cushing reported a mortality rate of $15.4 \% .^{8}$

The preoperative diagnostic modalities included radiography, which could visualize calcifications, alterations of bony structures, and shift of the pineal shadow. Encephalography and ventriculography with filling of cerebral ventricles with air were used as well. In fact, Torkildsen's first publications were devoted to the interpretation of ventriculograms..$^{57}$ Ventriculography by injection of air into the cerebral ventricles was first described by Dandy in $1918,{ }^{14}$ and in 1919 Dandy described encephalography by injection of air into the lumbar thecal sac. ${ }^{13}$ In 1923 , ventriculography was introduced in the Department of Neurology of the Rikshospitalet.

Torkildsen performed his first VCS on September 9, 1937, in a patient with obstructive hydrocephalus due to compression of the aqueduct of Sylvius by a pineal region tumor.

The operation was an innovative solution to the problem of treating noncommunicating hydrocephalus. The surgical method is illustrated in Fig. 2. A bur hole was placed for ventriculography via one of the occipital horns of the lateral ventricle. Next, a suboccipital craniotomy was performed and a rubber tube was connected between the occipital horn and the cisterna magna. A Nélaton catheter was placed extracranially underneath the scalp. Both ventricular puncture and suboccipital decompressive exploration were used on a routine basis at that time, so this procedure was a natural step. The procedure was done under local anesthesia.

The VCS procedure should be viewed in light of the methods of managing hydrocephalus available at that time.

\section{Treatment of Hydrocephalus Before World War II}

The surgical treatment of hydrocephalus began in the late 19th century, but the procedures developed before

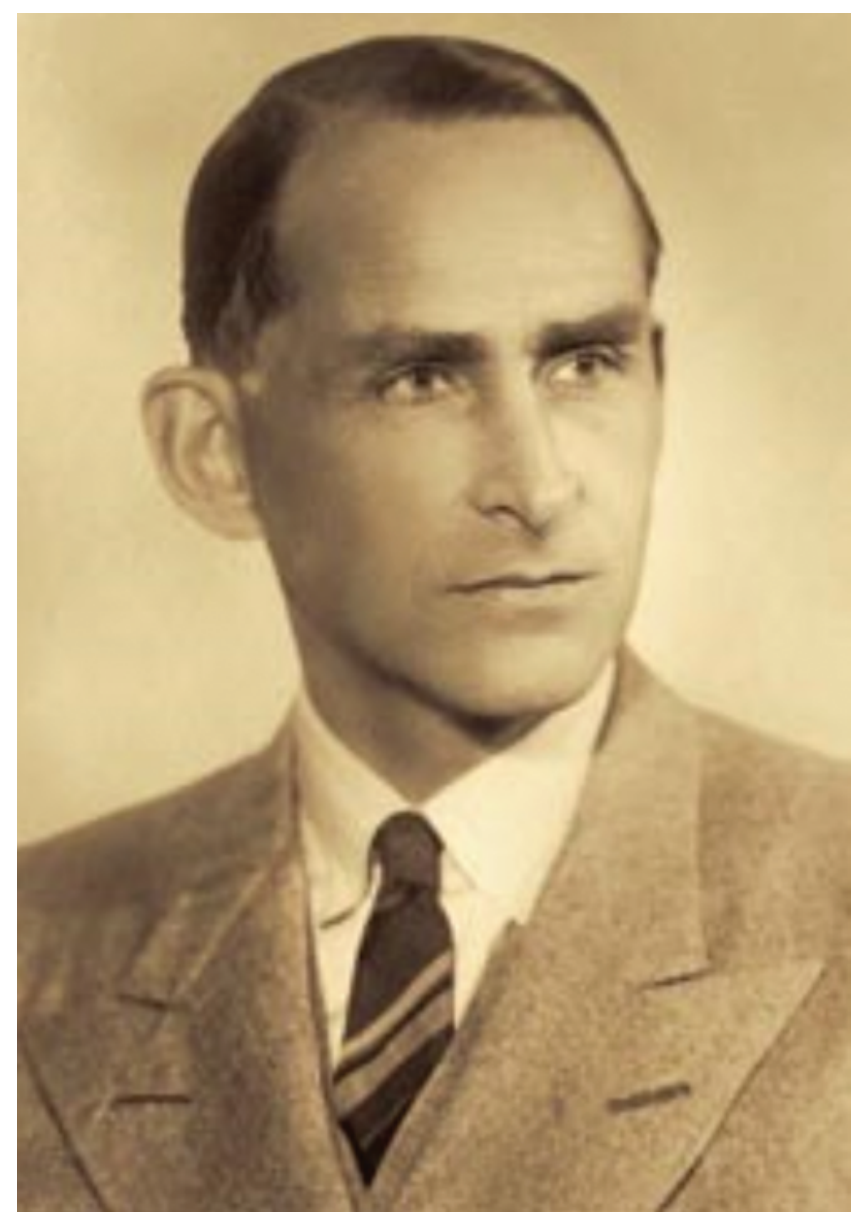

FIG. 1. Arne Torkildsen (1899-1968). Photograph circa 1939. Copyright Ragnar Stien. Published with permission. ${ }^{54}$ Figure is available in color online only.

World War II were challenging to perform and carried a high mortality rate. We briefly summarize the surgical treatment of hydrocephalus Torkildsen faced when he introduced the VCS in 1937. Others have previously provided comprehensive reviews of the history of hydrocephalus treatment. ${ }^{3,25,48}$

Beginning in 1913, Walter E. Dandy (1886-1946) of the Johns Hopkins Hospital in Baltimore published pioneering research on the physiology of the CSF circulation and the pathophysiology of hydrocephalus. ${ }^{.115-17}$ In describing CSF physiology, Dandy asserted that CSF is produced by the choroid plexus within the cerebral ventricles and enters the subarachnoid space via the foramina of Luschka and Magendie. He stressed that CSF is absorbed in the entire subarachnoid space and believed that absorption through the pacchionian granulations played a less important role. Absorption via the pacchionian granulations was proposed by Gustaf Key and Axel Retzius in $1875 .{ }^{36}$ Depending on the site of CSF obstruction, Dandy differentiated between noncommunicating and communicating hydrocephalus.

By the end of the 19th century, it became clear that CSF is actively produced and that repeated lumbar punctures could not cure hydrocephalus. In 1881, Carl Wernicke in- 

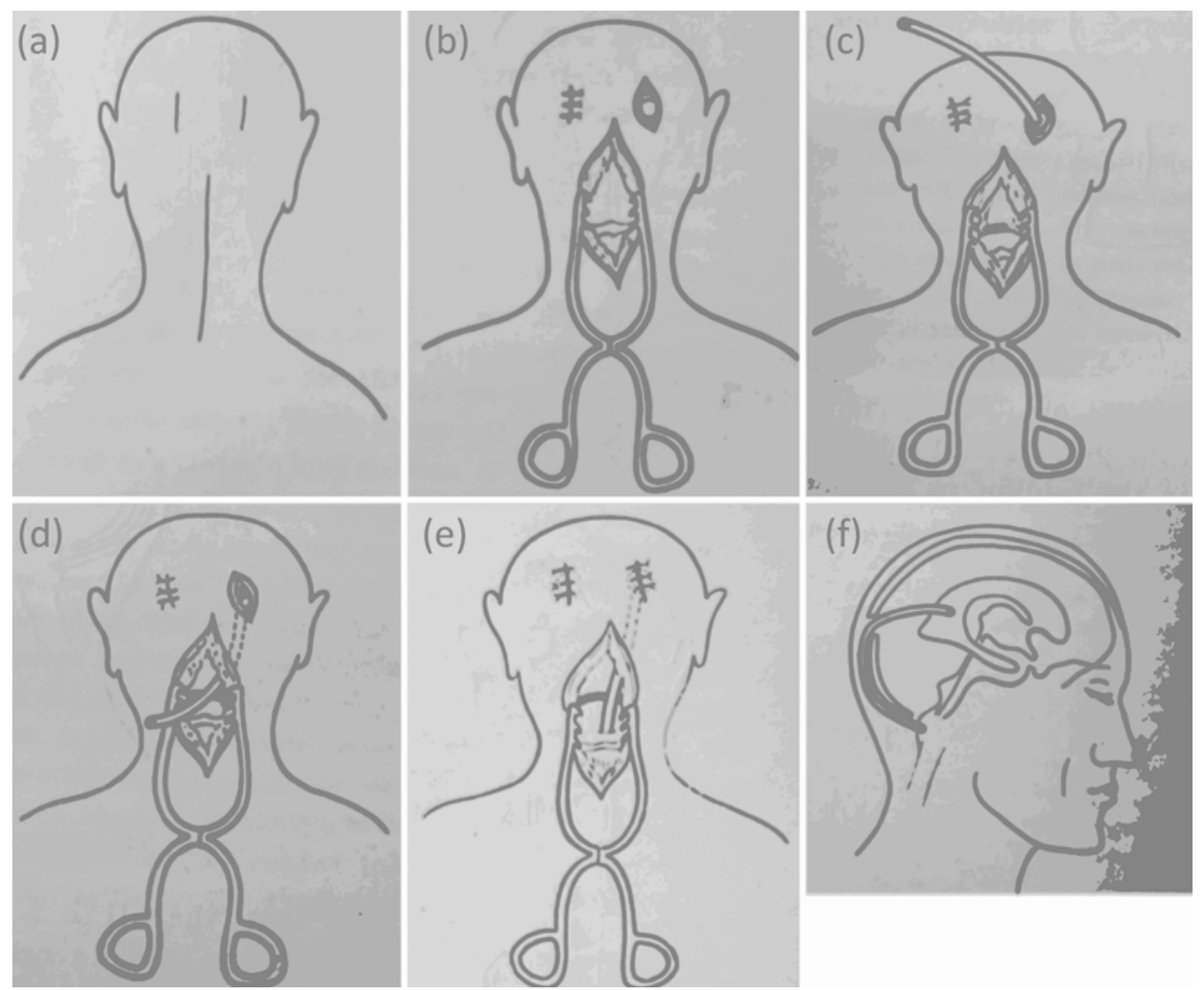

FIG. 2. The surgical steps in VCS, as described in Torkildsen's medical thesis, entitled Ventriculocisternostomy: A Palliative Operation in Different Types of Non-Communicating Hydrocephalus, and presented at the University of Oslo in 1947. Following a suboccipital midline incision (a), the suboccipital bone was exposed, and a craniectomy was performed (b). If Torkildsen found an infratentorial tumor, it was removed. In the absence of free CSF flow from the fourth ventricle, he performed a VCS. A catheter was placed in the occipital horn of the lateral ventricle via occipital trephination (c). The catheter was tunneled subcutaneously to the suboccipital opening (d) and then inserted into the cisterna magna (e). Panel (f) shows the Nélaton catheter extending from the occipital horn to the cisterna magna. Reproduced with permission from Universitetsforlaget AS, Oslo, Norway.

augurated sterile ventricular puncture and external CSF drainage..$^{63}$ The use of repeated lumbar punctures was first described by Heinrich Quincke in 1890, but this technique was soon abandoned as a treatment for hydrocephalus. ${ }^{50}$ Various attempts to drain the ventricles were subsequently tried.

According to W. Kausch, ${ }^{34}$ Dr. Pollock was the first to attempt to establish permanent drainage of CSF, in 1884. This was later also attempted by William W. Keen. ${ }^{35}$ Drainage was established using different materials such as horsehair, silver threads, and cannulas. Typically the CSF was drained to the surface of the head; however, the patients died either during surgery or immediately thereafter. Auguste Broca ${ }^{6}$ succeeded in keeping a cannula in place for 48 days. Numerous alternative drainage pathways were later invented, but these had a high failure rate due to insufficient implant materials in most cases.

The observation that spontaneous rupture might cause the CSF to escape to the surrounding soft tissues led to the idea that creating a communication to the surrounding tissues might lead to absorption of CSF outside the craniospinal thecal sac. R. Park ${ }^{45}$ first made a cervical laminectomy and opened the subarachnoid space to the soft tissue of the cervical region. However, it was soon realized that an impermeable membrane developed around the extracranial or extraspinal fluid, and these operations were abandoned.

In 1895 E. Gärtner ${ }^{24}$ proposed that a physiological treatment of hydrocephalus might be achieved by drainage of CSF from the subarachnoid space to the venous system. This was first attempted by E. Payr ${ }^{46}$ who transplanted a part of the saphenous vein between the ventricle and the superior sagittal sinus. One of his first patients lived for 6 months while another died during the perioperative period. Later, in 1913, Irving S. Haynes ${ }^{27}$ connected a cannula between the cisterna magna and the occipital sinus. Both of his patients died, and attempts to drain CSF into the venous system were discontinued for some time.

According to Kausch, ${ }^{34}$ Dr. Mikulicz in 1893 created a cortectomy into the ventricles for drainage into the subarachnoid space in a 7.5-month-old child. However, adhesion of the leptomeninges to the cortex soon prevented absorption of CSF. Other surgeons ${ }^{2}$ created an opening into the corpus callosum to drain CSF from the ventricles into the subarachnoid space; however, the opening in the corpus callosum tended to close, and arachnoid adhe- 
sions soon developed. Such approaches were used into the 1930s.

Drainage of CSF to the peritoneal cavity was described by A. H. Ferguson, ${ }^{21}$ who perforated the L-5 vertebra with a silver wire in an attempt to drain CSF from the spinal canal into the peritoneal cavity; both his patients died in the course of surgery. Cushing 9 attempted a similar approach but 3 of his patients died, probably due to intestinal invagination. He then abandoned the approach.

Drainage of CSF into the pleural cavity was also attempted, using a rubber tube to create a communication between the "lake" or "pseudocele" of CSF, induced by suboccipital decompression, and the pleural cavity. Due to connective tissue adhesions in the pleural cavity, repeated surgeries were needed to keep the rubber tube open. Therefore, this procedure was also discontinued.

Drainage of CSF into the urinary bladder was first attempted by B. Heile, ${ }^{28}$ who performed a nephrectomy and then implanted the ureter intraspinally. The procedure was attempted in a few initial cases, but the mortality rate was high. Heile used this procedure in 4 additional patients; $; 2$ died shortly after surgery, while the other 2 survived for 3 and 6 years, respectively. However, due to the high risk of complications and death, this procedure gained no practical importance.

Other approaches aimed at reducing the production of CSF. Irradiation of the choroid plexus with x-rays ${ }^{39}$ was done to reduce the production of CSF. O. Hildebrand first attempted surgical destruction of the choroid plexus in 1904 and repeated the procedure 1922. In both cases the outcome was fatal. ${ }^{31}$ The procedure was later successfully undertaken by Dandy and T. J. Putnam. ${ }^{49}$ Dandy advocated removal of the choroid plexus from both lateral ventricles and sometimes from the fourth ventricle. This technique was found to be useful in children, but not in cases of noncommunicating hydrocephalus.

Dandy's research and differentiation of noncommunicating and communicating hydrocephalus led to the development of operations for noncommunicating hydrocephalus aimed at restoring the passage of CSF through the aqueduct of Sylvius. Dandy ${ }^{12}$ described a ventriculostomy wherein an opening was made in the floor of the third ventricle that allowed CSF to escape into the surrounding subarachnoid space. In Dandy's series, 24 of 29 patients did well after this approach. The mortality rate in those younger than 1 year was $50 \%$. This approach required dilation of the third ventricle and was not useful when the third ventricle was occluded by tumor. Moreover, the ventriculostomy tended to close because of adhesions.

Another approach was dilation of the aqueduct of Sylvius by introducing a catheter into the aqueduct. Dandy ${ }^{12}$ also let a fine catheter remain in the aqueduct for some weeks; however, this operation was accompanied by a $50 \%$ mortality rate and secondary closures, which caused Dandy to abandon the procedure.

Taken together, in the 1930s surgical treatment of hydrocephalus remained a major challenge. The open anterior ventriculostomy to the third ventricle, introduced by Dandy, was the most common procedure for treating noncommunicating hydrocephalus. Obviously, this procedure was not useful when the third ventricle itself was com- pressed or occupied by tumor, and the procedure carried a high risk. The other common procedures were open coagulation (or extirpation) of the choroid plexus in communicating hydrocephalus, open puncture of the ventricles, and even dehydration. Torkildsen aimed at improving the ventriculostomy already introduced by Dandy.

\section{Torkildsen's Ventriculocisternostomy Procedures}

Torkildsen had reviewed his first three experiences with VCS in a presentation at the Eighth Congress of Scandinavian Neurologists in $1938 .{ }^{59}$ In 1947 , he was to defend his thesis on VCS, entitled Ventriculocisternostomy: A Palliative Operation in Different Types of Non-Communicating Hydrocephalus, at the University of Oslo. ${ }^{62}$ The doctoral thesis described 32 cases in which VCS was performed to treat tumors in the pineal region $(n=8)$, tumors of the third ventricle or its walls outside the pineal region $(\mathrm{n}=$ $11)$, or occlusion of the aqueduct of Sylvius $(n=13)$. Seven patients (22\%) died after VCS; among the remaining 25 patients, 19 were followed for 1 year or more. Within these respective groups, the mortality rates were $13 \%, 18 \%$, and $31 \%$. Regarding outcome, Torkildsen concluded that 18 of 32 patients (56\%) lived for more than 2 years and that 13 of the patients who survived to adulthood were able to earn their own living.

Regarding surgical mortality, it must be borne in mind that these patients had severe diseases and were admitted to the hospital at an advanced stage of disease progression. For several of the patients the surgery was their last resort. At that time, surgical removal of pineal tumors was associated with a high mortality rate. W. O. Russell and E. Sachs reviewed the literature and found that of 58 patients receiving surgery for pineal tumors, 55 died as a consequence of the surgery. ${ }^{52}$ Moreover, in a series of 21 cases of neoplasm in the third ventricle (5 colloid cysts, 16 neoplasms of other origins), the surgical mortality rate was $33 \% .10$

\section{Doctoral Dissertation}

During Torkildsen's examination and defense of his dissertation before the doctoral committee in February 1948, it became clear that additional patients had undergone VCS but were not included in the thesis. Later on, it turned out that an additional 16 patients had undergone VCS. Torkildsen wrote an addendum in 1948, 55 including all patients (the original 32 and the additional 16). He considered the 16 additional patients to have suffered from conditions outside the scope of the dissertation and asserted that their inclusion did not alter the conclusions of his thesis. The committee assessing the dissertation concluded that the thesis should be accepted for the Doctor of Medicine (Norwegian) degree. However, in 1948 the Faculty of Medicine, University of Oslo, refused to grant Torkildsen's doctoral degree. He then defended his thesis at the University of Copenhagen, Denmark, in October 1950, and obtained the degree of Doctor of Medicine, the same degree he was denied in Oslo. At the Rikshospitalet in Oslo, however, he was found not qualified for the post of associate professor in neurosurgery in spite of being rec- 
ommended by 2 international adjudicating committees on 4 occasions.

\section{Torkildsen's Last Years}

Due to the turbulence regarding the doctoral dissertation, Torkildsen left Norway. He then became professor of neurosurgery at the University of Cairo, Egypt, from 1951 to 1954 . After returning to Norway in 1954 , he practiced privately in the same clinic (Røde Kors Klinikk) in which Vilhelm Magnus had practiced until 1929.

In 1945, 14 of the patients who had undergone the VCS procedure remained alive. At follow-up, 14-20 years after surgery, 6 were alive, all in good condition. Evidence of occlusion was seen in only 1 patient. In 1960 Torkildsen's last publication on the VCS procedure appeared. ${ }^{56}$

Torkildsen died on March 7, 1968, of a degenerative brain disease of several years' duration. ${ }^{37}$ He received honorary memberships in the Society of British Neurological Surgeons in 1961 and the Nordic Neurosurgical Society in 1963, and also received honorary memberships in neurosurgical societies in Italy and Argentina.

\section{Other Experiences With VCS}

VCS was the first clinically successful shunting procedure for CSF diversion in hydrocephalus and received international acceptance. ${ }^{32,33,53}$ J. E. Scarff ${ }^{53}$ collected 136 reported outcomes for the procedure in 1963; the operative mortality rate was $30 \%$, and the initial arrest of hydrocephalus occurred on average in 58\% of cases during 2 years of follow-up. Several neurosurgeons started using the approach in the 1940s, ${ }^{22,47,64}$ and various modifications of the original procedure were created. $22,26,30,40,44,47,53$ For example, in their report of 1948, Fincher et al. ${ }^{22}$ reported on 19 patients, 11 of whom were alive after 7-36 months, with good clinical results. The surgical mortality rate was $37 \%$ (7/19 patients). In 25 cases reported by Paine and McKissock, ${ }^{44}$ there were 5 postoperative deaths $(20 \%)$ and clinically satisfactory results in 18 patients $(73 \%)$. The procedure remained an important operation during the 1940s and 1950s, until the introduction of extracranial shunts.

In 1949, Nulsen and Spitz ${ }^{43}$ successfully implanted a shunt with a ball valve into the superior vena cava. ${ }^{5}$ In 1957, John Holter introduced the Holter valve for ventriculoperitoneal shunts. ${ }^{4}$ This new procedure replaced the VCS, which, however, continued to be used for certain indications such as tumors in the third ventricle and aqueduct obstruction..$^{18}$ In our neurosurgical department at Oslo University Hospital, the VCS continued to be used in selected cases until about 1987. ${ }^{38}$ Although catheter obstruction was observed rather frequently, lasting results over many years were seen. ${ }^{65}$ While some authors ${ }^{1}$ regarded the Torkildsen procedure as an "obsolete surgical procedure," Morota et al. ${ }^{42}$ more recently argued for its role in obstructive hydrocephalus due to lesions in and around the third ventricle. They concluded that the best candidates for the Torkildsen shunt are those patients who have lesions in and around the third and fourth ventricles, which preclude endoscopic third ventriculostomy. ${ }^{42}$ One advantage of the Torkildsen shunt is that it enables physiological CSF drainage, thus avoiding the complications of shunting CSF to an extracranial compartment. The disadvantage is that it is impossible to check shunt function, although placement of a CSF reservoir in the shunt catheter would solve this problem.

The Torkildsen procedure is associated with a number of important early and late complications: ${ }^{18}$ myelopathy from physical contact of the distal end of the catheter with the neuraxis; acute quadriparesis following placement of the catheter in the cervical subarachnoid space along the spinal cord; death due to penetration of the cervicomedullary junction by the catheter; and obstruction of the catheter, for example, due to kinking. ${ }^{18}$ Other known complications are subdural hygroma ${ }^{41}$ and foreign body reactions to the rubber tube. ${ }^{51}$

\section{Case Reports Illustrating Torkildsen's Management of Hydrocephalus}

In patients with clinical signs and symptoms of increased intracranial pressure, Torkildsen performed ventriculography, which might provide indirect information on hemispheric or intraventricular surpratentorial pathology. If the examination revealed ventriculomegaly without movement of contrast into the posterior fossa, he opened the posterior fossa to look for an expansive lesion and resected the tumor when possible. If no tumor was found, he opened the fourth ventricle to determine whether CSF was passing through the aqueduct. If there was no movement of CSF from above, he placed his rubber catheter through a bur hole into the lateral ventricle and implanted the other end into the cisterna magna.

\section{Case 1}

A baby boy developed abnormal head growth shortly after birth, and a ventriculogram obtained in 1942 demonstrated large symmetrical dilation of the lateral ventricles. Ophthalmological examination showed atrophy of both optic discs. Due to further clinical progression during the following year, a VCS was performed under local anesthesia on December 10, 1943, at 21 months of age. During the operation, it was noticed that little or no fluid entered the fourth ventricle through the aqueduct of Sylvius.

When the boy was seen at follow-up 2 years later, growth of the head was no longer detected and there were no signs of intracranial hypertension.

This patient was examined again in December 1958, 15 years after the VCS. His physical development had been uneventful although his mental development was slightly retarded. The photographs in Fig. 3 show the patient at the time of VCS (1943), and at follow-up in 1946 and 1959, revealing normalization of the previously markedly enlarged head.

He attended a school for handicraft and seemed to do well. The head circumference was $61 \mathrm{~cm}$. As an adult, he lived independently and was in a protected employment environment.

The patient died in 1996, and his VCS appears to have functioned for 52 years.

\section{Case 2}

A 4-year-old boy presented with clinical symptoms of 

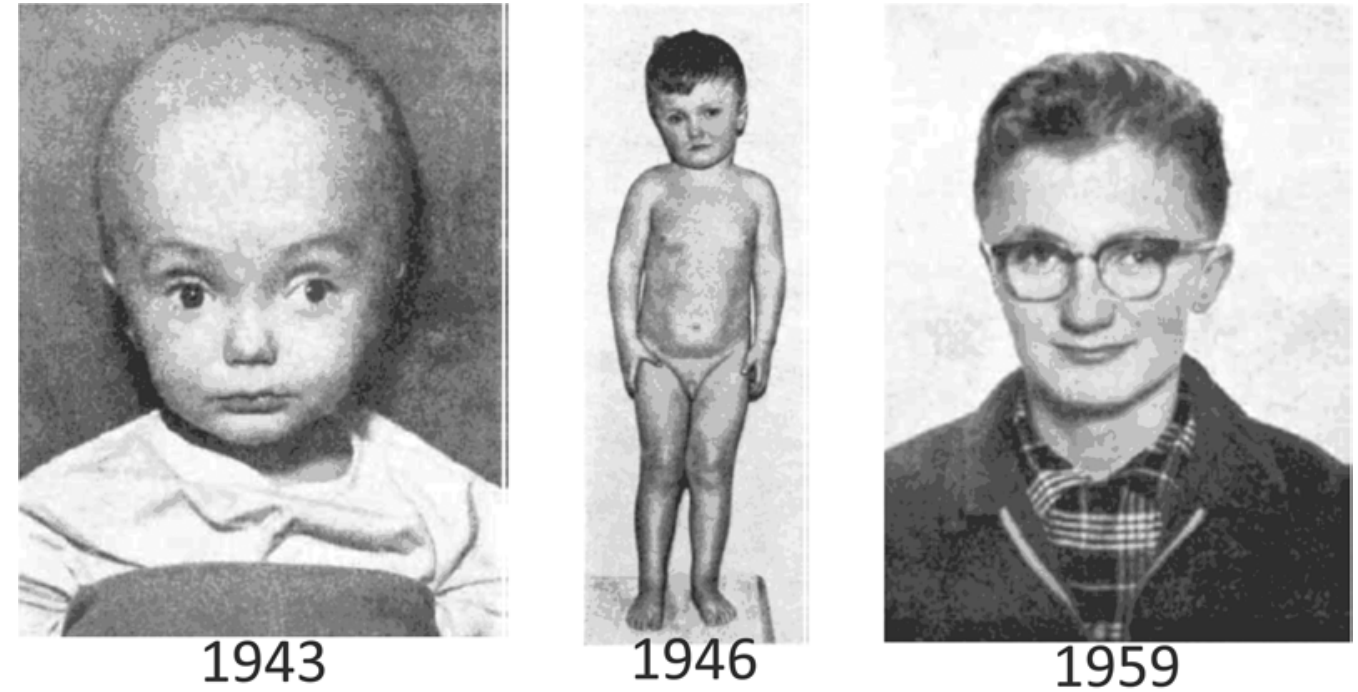

FIG. 3. Photographs of the patient in Case 1 in 1943, 1946, and 1959, as presented by Torkildsen in 1960. This boy was able to live independently and was employed in a protected work environment. When he died in 1996, his VCS appeared to have been functioning for 52 years. From Torkildsen A: A follow-up study 14 to 20 years after ventriculocisternostomy. Acta Psychiatr Scand 35:113-121, 1960. @ John Wiley \& Sons A/S. Reprinted with permission.

increased intracranial pressure with headache and vomiting. Ophthalmological examination revealed papilledema. On March 1, 1946, ventriculography showed triventricular hydrocephalus without contrast filling in the posterior fossa. Torkildsen then performed a subtentorial craniectomy using local anesthesia and found and removed a cystic cerebellar tumor. A bone graft from the tibia was used to repair some of the suboccipital bone deficiency. The boy recovered quite well during the following year and returned to a normal school program.

Later on, he was trained at a sawmill and advanced to the position of chief carpenter. He married and had 3 children and remained in full-time employment until age 65 . At clinical follow-up in 2012, there were no neurological deficits, and his score on the SARA (Scale for the Assessment and Rating of Ataxia) test, which assesses cerebellar dysfunction, was normal.
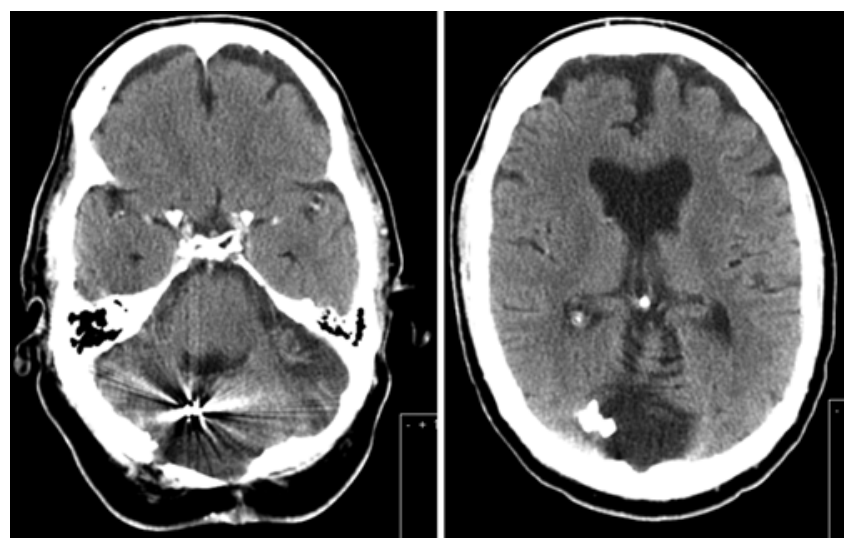

FIG. 4. CT scans of the patient in Case 2 obtained 64 years after removal of a cystic cerebellar tumor. Torkildsen performed the surgery in 1946 when the patient was 4 years old. He lived a normal life with his wife and three children. He retired at age 65 from his occupation as a chief carpenter and is still clinically well.
A CT study (Fig. 4) scan obtained in 2010, 64 years after the surgery, reveals local changes in the operative area without any signs of residual tumor. He is still clinically well, 68 years after surgery.

\section{Arne Torkildsen's Legacy}

The VCS procedure introduced by Arne Torkildsen in 1937 was the first clinically successful shunting procedure for CSF diversion in hydrocephalus. Although his doctoral thesis on VCS was rejected by the University of Oslo Faculty of Medicine, Torkildsen developed a procedure that received international recognition and was successfully used by many neurosurgeons around the world at a time when no other safe and effective treatment existed for patients with obstructive hydrocephalus. Torkildsen introduced neurosurgery as a clinical and academic specialty at the Rikshospitalet in Oslo and paved the way for the establishment of the Department of Neurosurgery in this hospital in 1951.

\section{Acknowledgment}

Funding for this study was provided by the Department of Neurosurgery, Oslo University Hospital-Rikshospitalet, Oslo, Norway.

\section{References}

1. Alp MS: What is a Torkildsen shunt? Surg Neurol 43:405406, 1995

2. Anton G, von Bramann FG: Balkenstich bei Hydrozephalien, Tumoren und bei Epilepsie. München Med Wehnschr 55:1673-1677, 1908

3. Aschoff A, Kremer P, Hashemi B, Kunze S: The scientific history of hydrocephalus and its treatment. Neurosurg Rev 22:67-95, 1999 
4. Baru JS, Bloom DA, Muraszko K, Koop CE: John Holter's shunt. J Am Coll Surg 192:79-85, 2001

5. Boockvar JA, Loudon W, Sutton LN: Development of the Spitz-Holter valve in Philadelphia. J Neurosurg 95:145-147, 2001

6. Broca A: Drainage des ventricules cérébraux pour hydrocéphalie. Revde Chir (Paris) 11:37-52, 1891

7. Cushing HW: Experiences with the cerebellar astrocytomas. A critical review of seventy-six cases. Surg Gynecol Obstet 52:129-204, 1931

8. Cushing HW: Intracranial Tumours: Notes Upon a Series of Two Thousand Verified Cases With Surgical-Mortality Percentages Pertaining Thereto. Springfield, IL: Charles C Thomas, 1932

9. Cushing HW: Studies in Intracranial Physiology \& Surgery: the Third Circulation, the Hypophysis, the Gliomas. Oxford: Oxford University Press, 1926

10. Dandy WE: Benign Tumors in the Third Ventricle of the Brain: Diagnosis and Treatment. Springfield, IL: Charles C Thomas, 1933

11. Dandy WE: Experimental hydrocephalus. Ann Surg 70:129142, 1919

12. Dandy WE: An operative procedure for hydrocephalus. Johns Hopkins Hosp Bull 33:189-190, 1922

13. Dandy WE: Röntgenography of the brain after the injection of air into the spinal canal. Ann Surg 70:397-403, 1919

14. Dandy WE: Ventriculography following the injection of air into the cerebral ventricles. Ann Surg 68:5-11, 1918

15. Dandy WE: Where is cerebrospinal fluid absorbed? JAMA 92:2012-2014, 1929

16. Dandy WE, Blackfan KD: An experimental and clinical study of internal hydrocephalus. JAMA 61:2216-2217, 1913

17. Dandy WE, Blackfan KD: Internal hydrocephalus: An experimental, clinical and pathological study. Am J Dis Child 8:406-482, 1914

18. Ehni G, Moiel RH, Bragg TG: Torkildsen's ventriculocisternostomy: some complications and their prevention. Clin Neurol Neurosurg 79:119-132, 1976

19. Evans JP: Wilder Penfield: his legacy to neurology. Exciting beginnings. Can Med Assoc J 116:1367, 1977

20. Feindel W: Wilder Penfield (1891-1976): The man and his work. Neurosurgery 1:93-100, 1977

21. Ferguson $\mathrm{AH}$ : Intraperitoneal diversion of the cerebrospinal fluid in cases of hydrocephalus. N Y Med J 67:902-909, 1898

22. Fincher EF, Strewler GJ, Swanson HS: The Torkildsen procedure; a report of 19 cases. J Neurosurg 5:213-229, 1948

23. Fodstad H, Ljunggren B, Kristiansen K: Vilhelm Magnuspioneer neurosurgeon. J Neurosurg 73:317-330, 1990

24. Gärtner E: Diskussionsbemerkung. Naturforscherversammlung (Lübeck) 2:146, 1895

25. Gjerris F, Snorrason E: The history of hydrocephalus. J Hist Neurosci 1:285-312, 1992

26. Graf CJ, Hamby WB: A modification of Torkildsen's ventriculocisternostomy. J Neurosurg 14:470-472, 1957

27. Haynes IS: Congenital internal hydrocephalus. Its treatment by drainage of the cisterna magna into the cranial sinuses. Ann Surg 57:449-484, 1913

28. Heile B: Über neue operative Wege zur Druckentlastnung bei angeborenem Hydrocephalus (Ureter-Duraanastomose). Zentralbl Chir 52:2229-2236, 1925

29. Heile B: Zur Behandlung des Hydrocephalus mit UreterDuraanastomose. Zentralbl Chir 54:1859-1864, 1927

30. Herlin L: Ventriculocisternostomy according to Torkildsen; a report of twenty-two cases. J Neurosurg 7:403-411, 1950

31. Hildebrand O: Eine neue Operationsmethode zur Behandlung des Hydrocephalus int chron der Kinder. Arch Klin Chir 127:178-194, 1923

32. Ingraham FD, Matson DD: Hydrocephalus, in Ingraham FD,
Matson, DD (eds): Neurosurgery of Infancy and Childhood. Springfield, IL: Charles C Thomas, 1954, pp 117-156

33. Jackson IJ: A review of the surgical treatment of internal hydrocephalus. J Pediatr 38:251-258, 1951

34. Kausch W: Die Behandlung des Hydrocephalus der kleinen Kinder. Arch Clin Chir 87:709-796, 1908

35. Keen WW: Tapping the ventricles. BMJ 1:486, 1891 (Letter)

36. Key A, Retzius G: Studien in der Anatomie des Nervensystems und des Bindegewebes. Stockholm: Samson and Wallin, 1875

37. Kristiansen K: Arne Torkildsen (1899-1968). J Neurol Sci 7:606-607, 1968

38. Lundar T, Nakstad P: [Torkildsen's operation -50 years later.] Tidsskr Nor Laegeforen 110:584-586, 1990 (Norwegian)

39. Marburg O: Versuche einer nichtoperativen Beeinflussung hirndrucksteigender Prozesse. Wien Klin Wochenschr 51:1017-1018, 1924

40. Matson DD: Current treatment of infantile hydrocephalus. $\mathbf{N}$ Engl J Med 255:933-936, 1956

41. Meredith JM: Massive subdural hydroma complicating Torkildsen procedure for posterior third ventricle or pineal tumor. J Neurosurg 15:464-467, 1958

42. Morota N, Ihara S, Araki T: Torkildsen shunt: re-evaluation of the historical procedure. Childs Nerv Syst 26:1705-1710, 2010

43. Nulsen FE, Spitz EB: Treatment of hydrocephalus by direct shunt from ventricle to jugular vein. Surg Forum 1951:399403, 1951

44. Paine KW, McKissock W: Aqueduct stenosis; clinical aspects, and results of treatment by ventriculocisternostomy (Torkildsen's operation). J Neurosurg 12:127-145, 1955

45. Park R: The nature and operative treatment of hydrocephalus: Drainage from the lower end of the spinal canal; report of a case. Med News N Y 70:432-435, 1897

46. Payr E: Drainage der Hirnventrikel mittels frei transplantierter Blutgefäße; Bemerkungen über Hydrocephalus. Arch Klin Chir 87:801-885, 1908

47. Penfield W: The Torkildsen procedure for inoperable occlusion of the sylvian aqueduct. Can Med Assoc J 47:62-63, 1942

48. Pudenz RH: The surgical treatment of hydrocephalus-an historical review. Surg Neurol 15:15-26, 1981

49. Putnam TJ: Treatment of hydrocephalus by endoscopic coagulation of the choroid plexus. Description of a new instrument and preliminary report of results. N Engl J Med 210:1373-1376, 1934

50. Quincke H: Die Lumbalpunction des Hydrocephalus. Berl Clin Wschr 28:929-933, 1891

51. Rossitch E Jr, Friedman AH, Bullard DE: Foreign body reaction to rubber Torkildsen catheters: a report of two cases. Neurosurgery 17:838-842, 1985

52. Russell WO, Sachs E: Pinealoma. A clinicopathologic study of seven cases with review of the literature. Arch Pathol (Chic) 35:869-888, 1943

53. Scarff JE: Treatment of hydrocephalus: an historical and critical review of methods and results. J Neurol Neurosurg Psychiatry 26:1-26, 1963

54. Stien R, Aarli JA: [Skeletons in the cupboard-treatment of Arne Torkildsen.] Tidsskr Nor Laegeforen 123:3588-3591, 2003 (Norwegian)

55. Torkildsen A: Addendum ad Ventriculocisternostomy. Oslo: Grøndal \& Søns, 1948, pp 1-16

56. Torkildsen A: A follow-up study 14 to 20 years after ventriculocisternostomy. Acta Psychiatr Scand 35:113-121, 1960

57. Torkildsen A: The gross anatomy of the lateral ventricles. J Anat 68:480-491, 1934

58. Torkildsen A: Intrakraniell kirurgi. Erfaringer fra Rikshospitalets Nerveavdeling 1935-1938. Oslo: Rikshospitalet, 1939 
59. Torkildsen A: A new palliative operation in cases of inoperable occlusion of the Sylvian aqueduct. Acta Psychiatr Scand 14:221, 1939

60. Torkildsen A: A report on 472 cases of head injury treated in the Royal Victoria Hospital, Montreal. Acta Psychiatr Scand 10:643-655, 1935

61. Torkildsen A: Tumours of the glioma group. Acta Psychiatr Scand 10:163-196, 1935

62. Torkildsen A: Ventriculocisternostomy: A Palliative Operation in Different Types of Non-Communicating Hydrocephalus. Oslo: University of Oslo, 1947, pp 1-240

63. Wernicke C: Lehrbuch der Gehirnkrankheiten für Aertzte und Studirende. Kassel, Germany: Fischer, 1881

64. Wilson AA: Ventriculocisternostomy (report of four cases). W V Med J 42:114-119, 1946

65. Zinn PO, Bozinov O, Burkhardt JK, Reisch R, Yaşargil MG, Bertalanffy H: Failure of a Torkildsen shunt after functioning for 50 years. J Neurosurg 112:796-799, 2010

\section{Disclosure}

The authors report no conflict of interest concerning the materials or methods used in this study or the findings specified in this paper.

\section{Author Contributions}

Conception and design: both authors. Acquisition of data: both authors. Analysis and interpretation of data: both authors. Drafting the article: both authors. Critically revising the article: both authors. Reviewed submitted version of manuscript: both authors. Approved the final version of the manuscript on behalf of both authors: Eide. Administrative/technical/material support: Eide.

\section{Correspondence}

Per Kristian Eide, Oslo University Hospital-Rikshospitalet, PB 4950 Nydalen, 0424 Oslo, Norway. email: peide@ous-hf.no. 